\title{
Purification of Ribonuclease $T_{1}$ by Diethylaminoethylcellulose Chromatography
}

\author{
BY ROBERT FIELDS, HENRY B. F. DIXON AND GILLIAN R. LAW \\ Department of Biochemistry, University of Cambridge, Tennis Court Road, Cambridge, CB2 1QW, U.K. \\ AND CHIE YUI* \\ Department of Biophysics and Biochemistry, Faculty of Science, University of Tokyo, Japan
}

(Received 22 October 1970)

\begin{abstract}
A procedure is described for isolating the enzyme ribonuclease $T_{1}$ from Takadiastase, an extract of the mould Aspergillus oryzae. It involves an initial concentration of the enzyme by adsorption on DEAE-cellulose followed by gradient elution. Later the enzyme is chromatographed on the same adsorbent with an eluent of constant composition. Yields of $350-380 \mathrm{mg}$ of ribonuclease $T_{1}$ from $500 \mathrm{~g}$ of Takadiastase were obtained.
\end{abstract}

The well-known specificity of ribonuclease $T_{1}$ (EC 2.7.7.26) from Aspergillus oryzae for catalysing $2^{\prime}: 3^{\prime}$-phosphate cyclization of guanylonucleotides in RNA and the subsequent hydrolysis of these esters has made it a reagent of value in the determination of nucleotide sequence (Holley et al. 1965; Brownlee, Sanger \& Barrell, 1968). The use of ribonuclease $T_{1}$ for synthesis of oligoribonucleotides of defined base sequence (Mohr \& Thach, 1969) has shown that yields may be obtained that compare favourably with other methods of synthesis.

The molecule is small (mol.wt. 11085), it is stable to acid and heat, and its primary structure has been determined; it is inhibited by iodoacetate, which reacts with a highly reactive carboxyl group, and not with histidine, as with ribonuclease $\mathbf{A}$, the main chromatographic component of bovine pancreatic ribonuclease. For recent reviews on ribonuclease $\mathbf{T}_{1}$ see Takahashi, Uchida \& Egami (1970), Egami \& Nakamura (1969) and Barnard (1969).

In view of the extensive amount of scientific study that has been made of ribonuclease $A$, including a determination of the three-dimensional structure of the crystalline enzyme (Kartha, Bello \& Harker, 1967; Wyckoff et al. 1967), the value of further experimental work with ribonuclease $T_{1}$ is particularly enhanced. The procedure described here was developed in order to obtain $100 \mathrm{mg}$ quantities of ribonuclease $T_{1}$ for such studies.

* Present address: Department of Biochemistry, National Cancer Center Research Institute, 5-1-1, Tsukiji, Chuo-ku, Tokyo, Japan.

\section{MATERIALS}

Samples of the Takadiastase powders Sanzyme R, Y and A were kind gifts from Professor F. Egami and from the Sankyo Co. Ltd., Central Research Laboratories, 2-58, 1-chome, Hiromachi, Shinagawa-ku, Tokyo, Japan; Sanzyme 3500 was purchased from the Sankyo Co. through Micro-Bio Laboratories, London W.11, U.K. We did not find much difference in the yield of ribonuclease $T_{1}$ between these powders, although the total ribonuclease activity of Sanzyme 3500 was the highest (Table 1). Microgranular DEAE-cellulose (Whatman DE-52) was obtained from Whatman Biochemicals Ltd., Maidstone, Kent, U.K., much of it as a gift. The glass columns used for chromatography had sintered-glass bottoms and were made by Wesley Coe Ltd., Cambridge, U.K.

\section{METHODS}

Enzyme assays. For the determination of specific activity of the purified ribonuclease $T_{1}$ the standard procedure of Takahashi (1961) was used, as follows. A mixture of $0.1 \mathrm{ml}$ of enzyme solution, $0.25 \mathrm{ml}$ of $0.2 \mathrm{M}$-trisHCl buffer, $\mathrm{pH} 7.5,0.1 \mathrm{ml}$ of $20 \mathrm{~mm}$-EDTA (disodium salt), and $0.25 \mathrm{ml}$ of $0.3 \%$ RNA was incubated for $15 \mathrm{~min}$ at $37^{\circ} \mathrm{C}$. The reaction was stopped with $0.25 \mathrm{ml}$ of $0.75 \%$ uranyl acetate in $25 \%(\mathrm{w} / \mathrm{v}) \mathrm{HClO}_{4}$, the mixture was centrifuged, and $0.2 \mathrm{ml}$ of the supernatant was diluted to $5.0 \mathrm{ml}$ with water before determination of its extinction at $260 \mathrm{~nm}$. The amount of enzyme that caused an increase in $E_{260}$ of 1.0 under these conditions was defined as one enzyme unit. The specific activity was defined as the ratio of the number of enzyme units in $0.1 \mathrm{ml}$ of sample solution divided by the extinction at $280 \mathrm{~nm}$ of the same solution. For routine measurements a procedure based on that of Kalnitsky, Hummel \& Dierks (1959) was found 
to be more convenient. A sample of enzyme (2-50 $\mu \mathrm{l})$ was added to $1.5 \mathrm{ml}$ of $0.2 \mathrm{M}$-sodium acetate buffer, pH4.7, containing $20 \mathrm{~mm}$-EDTA. The reaction was initiated by adding to this $0.5 \mathrm{ml}$ of yeast RNA $(10 \mathrm{mg} / \mathrm{ml})$ solution and mixing in a Vortex mixer. After 5-60min at room temperature, depending on the sensitivity desired, $0.5 \mathrm{ml}$ of $0.75 \%$ uranyl acetate in $25 \%$ (w/v) $\mathrm{HClO}_{4}$ was added, the tubes were centrifuged, and $0.2 \mathrm{ml}$ samples of the supernatant were each diluted to approx. $5 \mathrm{ml}$ with water. The assay was standardized by comparison with a standard curve made by assaying ribonuclease $T_{1}$ of known specific activity under these same conditions. Amylase activity was determined by a procedure similar to that of Fuwa (1954) and the adenosine deaminase activity was measured with AMP as substrate (Minato, Tagawa \&

Table 1. Comparison of enzyme activities of Takadiastase powders

The activities of aqueous extracts $(40 \mathrm{ml}$ of water/g of powder) were measured at $\mathrm{pH} 7.5$, as described in the text. The unit of activity is as defined by Takahashi (1961).

$\begin{array}{cc}\text { Powder type } & \begin{array}{c}\text { Activity } \\ \text { (units/g of powder) }\end{array} \\ \text { R } & 2860 \\ \text { A } & 1980 \\ \text { Y } & 3060 \\ 3500 & 3140\end{array}$

Nakanishi, 1965). Ribonuclease $T_{2}$ activity was distinguished from that of ribonuclease $T_{1}$ by using the differential assay method of Takahashi (1961).

Chromatography. The phosphate buffers used were of two types, described below as 'neutral' and 'acid'. The neutral phosphate buffers were dilutions of a $0.5 \mathrm{M}$ stock solution that consisted of $0.2 \mathrm{M}-\mathrm{NaH}_{2} \mathrm{PO}_{4}$ and $0.3 \mathrm{M}$ $\mathrm{Na}_{2} \mathrm{H}_{1} \mathrm{PO}_{4}, \mathrm{pH}$ 6.9. The acid phosphate buffer used for the concentration step consisted of $0.08 \mathrm{M}-\mathrm{NaH}_{2} \mathrm{PO}_{4}$ and $0.02 \mathrm{M}-\mathrm{H}_{3} \mathrm{PO}_{4}$. It was made by mixing $100 \mathrm{ml}$ of the stock buffer and $50 \mathrm{ml}$ of $\mathrm{M}-\mathrm{H}_{3} \mathrm{PO}_{4}$ and diluting to 1 litre. The $\mathrm{M}-\mathrm{H}_{3} \mathrm{PO}_{4}$ was prepared by diluting $88 \%$ phosphoric acid and was standardized by titration with $\mathrm{M}-\mathrm{NaOH}$ to $\mathrm{pH} 4.5$.

The DEAE-cellulose (Whatman DE-52) was prepared as described by Dixon \& Thompson (1968) for CMcellulose. In this process fine particles that settled in dilute buffer at less than $2 \mathrm{~cm} / \mathrm{min}$ were largely removed. All columns were run at up to $2 \mathrm{ml} \cdot \mathrm{cm}^{-2} \cdot \mathrm{min}^{-1}$ for adsorption steps and at $0.5 \mathrm{ml} \cdot \mathrm{cm}^{-2} \cdot \min ^{-1}$ for elution or chromatography steps.

Extraction. Takadiastase powder $(500 \mathrm{~g})$ was divided equally between four $1250 \mathrm{ml}$ centrifuge bottles. Water $(625 \mathrm{ml})$ was added to each. No attempt was made to wet the powder at this stage, since the centrifugal force was found to be the most effective way of wetting and dissolving it (Uchida, 1965).

The bottles were centrifuged at approx. $2000 \mathrm{~g}$ for $10 \mathrm{~min}$ and the supernatant fluid was decanted off. A further $625 \mathrm{ml}$ portion of water was added to each bottle, and the residues were mixed thoroughly with a glass rod. After a second centrifugation and decantation, each

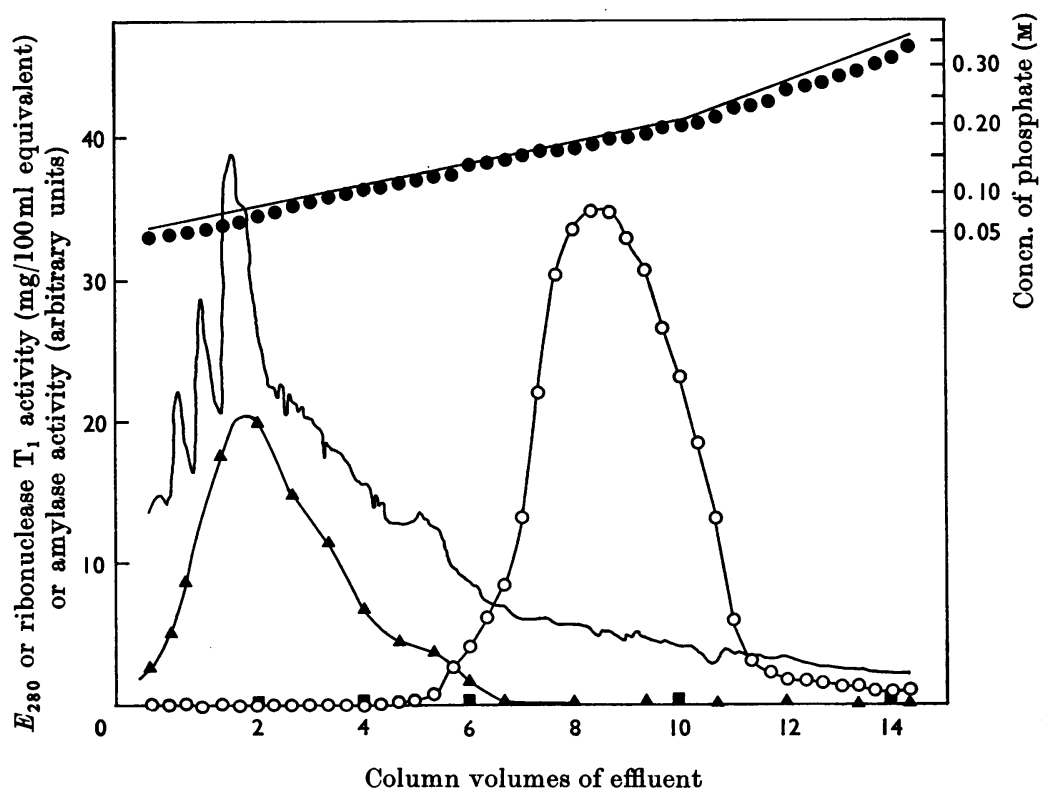

Fig. 1. Gradient chromatography on DEAE-cellulose of adsorbed material from an aqueous extract of $500 \mathrm{~g}$ of Takadiastase Y. The solid line shows the concentration of phosphate buffer, $\mathrm{pH} 6.9$, entering the column; -, concentration of phosphate in the effluent as determined by the conductivity. $O$, Ribonuclease activity; $\Delta$, amylase activity;,$- E_{280}$. The column had a packed bed of $9 \mathrm{~cm}$ in diameter and was $12 \mathrm{~cm}$ high. 
residue was finally extracted similarly with $375 \mathrm{ml}$ of water. The combined supernatant liquids were diluted to 20 litres.

Adsorption on DEAE-cellulose. Although Uchida (1965) used batchwise adsorption, we have found it more convenient to pass the extract through a column of the exchanger, and have found that 1-1.5 parts of exchanger ( $\mathrm{ml}$ of packed column volume/g of original powder) is sufficient to adsorb most of the ribonuclease $T_{1}$. A column of $9 \mathrm{~cm}$ diameter was packed with Whatman DE-52 as a slurry to a depth of $12 \mathrm{~cm}$ and equilibrated with $0.5 \mathrm{M}$ neutral phosphate buffer. It was then washed with $500 \mathrm{ml}$ of 0.05 M-phosphate. The 20 litres of diluted extract were passed through this at a flow rate of up to 7 litres/h (achieved by a head of about $2 \mathrm{~m}$ ). If any cracks appeared at the top of the column this was stirred. A float on the liquid over the bed protected the bed from being disturbed by the incoming jet of liquid. The operation of the column was checked by periodic assays on the effluent, which should show less than $20 \%$ of the activity at $\mathrm{pH} 4.7$ of the influent liquid.

Elution with a gradient of phosphate buffer. A linear gradient of 8 litres from 0.05 to $0.2 \mathrm{M}$ was then applied, followed by a linear gradient of 4 litres from 0.2 to $0.35 \mathrm{M}$. Fractions of volume $50 \mathrm{ml}$ were collected and every fifth was assayed for ribonuclease activity (Fig. 1). The active fractions were pooled.

Concentration. A concentration step is inserted here, since the following step would otherwise require a very large volume of solution. The principle is to adsorb the enzyme on DEAE-cellulose by diluting the phosphate enough so that the enzyme is strongly bound, and to displace it with a $0.1 \mathrm{~m}$-phosphate buffer at $\mathrm{pH} 2.8$. The pool from the previous step was diluted twofold with water and passed through a column $(9 \mathrm{~cm}$ diam. $\times 7 \mathrm{~cm})$ of Whatman DE-52 equilibrated with $0.1 \mathrm{M}$-phosphate buffer, pH 6.9. It was then eluted with the acid phosphate buffer. The front of equilibration to this new $\mathrm{pH}$ passes down the column retarded to about 2 column volumes. The enzyme emerges as a sharp band at this front and is collected in a small volume.

Removal of colour and other proteins. The fractions hitherto have contained material with a yellow-brown colour. Takahashi (1962) and Uchida (1965) removed this by treatment with Japanese acid clay or by repeated chromatography. Each of our chromatographic steps removes much of it, as some is less retarded on the DEAE. cellulose, and some is held more firmly, but as it always spreads out, whether due to heterogeneity or to slow equilibration with the exchanger, no step entirely removes it. We adsorb some of this material at this stage on DEAEcellulose under conditions such that the enzyme is just not adsorbed and $25-30 \%$ of other proteins are adsorbed. The pooled acid concentrate is adjusted to $\mathrm{pH} 2.8$ with $0.1 \mathrm{M}-\mathrm{H}_{3} \mathrm{PO}_{4}$ and diluted tenfold to give a concentration of $10 \mathrm{~mm}$. It is then passed through the column of Whatman DE-52 just used for concentration, after equilibration with a solution of $2 \mathrm{~mm}-\mathrm{H}_{3} \mathrm{PO}_{4}$ and $18 \mathrm{~mm}-\mathrm{NaH}_{2} \mathrm{PO}_{4}$ (a $1: 10$ dilution of the acid phosphate buffer). The column is finally washed with $500 \mathrm{ml}$ of this buffer and the pooled effluent is adjusted to pH 7. The coloured material and bound proteins are then eluted from the column with the $0.1 \mathrm{~m}$-acid phosphate. As a precaution, the residue that comes off is assayed for ribonuclease activity. On some

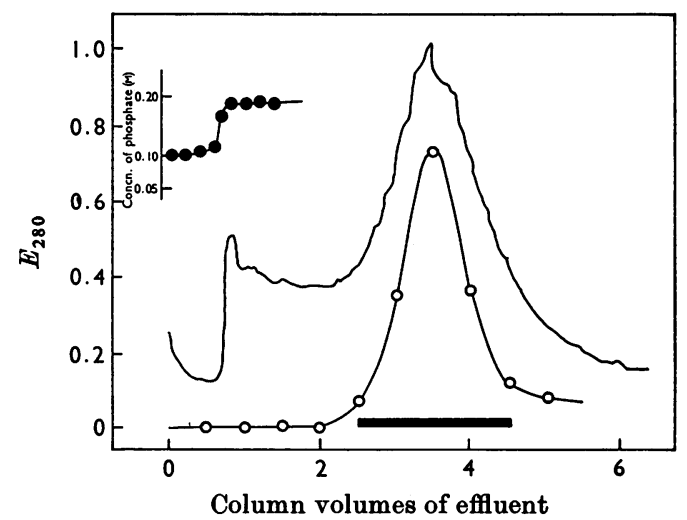

Fig. 2. First equilibrium chromatography of ribonuclease $T_{1}$. A column $(9 \mathrm{~cm}$ diam. $\times 15 \mathrm{~cm}$ high) of DEAEcellulose equilibrated to $0.1 \mathrm{~m}$-phosphate buffer, pH 6.9, was eluted by $0.19 \mathrm{~m}$-phosphate buffer, pH6.9. $E_{280}$; O, ribonuclease $T_{1}$ activity; $\bullet$, concn. of phosphate, determined by conductivity.

occasions ribonuclease was observed to bind to the column during this step, perhaps by complexing with other substances on the exchanger. If a significant amount of ribonuclease was found, this was saved along with the edges from chromatographic peaks and worked up separately.

First chromatography in a buffer of constant composition. Since the pool from the gradient is still crude, it is not possible to obtain highly purified ribonuclease in a single step by chromatography ina buffer of constant composition, since other substances present in the sample throw the column out of equilibrium. Nevertheless significant purification is achieved, and as the step is preliminary quite a short column is convenient. A buffer of lower eluting power than that which may be most convenient for chromatography of the purified enzyme is applied to make allowance for the facts that the exchanger's binding of the enzyme is altered by the mass of impurities and that considerable retardation is prudent when a short column is used. The pool from the previous step was applied to the $9 \mathrm{~cm}$-diameter column that was packed to a height of $15 \mathrm{~cm}$ with Whatman DE-52 freshly equilibrated with $0.1 \mathrm{~m}$-neutral phosphate. When the sample had been applied, the column was washed with 0.1 m-phosphate buffer until it was re-equilibrated (about 2 column volumes required) as shown by the $\mathrm{pH}$ and conductivity of the effluent. It was then eluted with $0.19 \mathrm{M}$ phosphate buffer (Fig. 2). The fact that the peak of activity emerged after re-equilibration of the column to the new conditions implies that it has moved down the column chromatographing with a finite partition coefficient, and is not simply displaced by a front of changed conditions.

The effluent that represented the peak of ribonuclease activity was concentrated as before and the concentrate adjusted to $\mathrm{pH} 7$.

Final chromatography. The concentrate at $\mathrm{pH} 7$, in a buffer of about $0.1 \mathrm{~m}$-phosphate, was run into the top of a column $(60 \mathrm{~cm}$ high $\times 4 \mathrm{~cm})$ of DEAE-cellulose, equilibrated with a buffer of 0.1 m-neutral phosphate. After the 


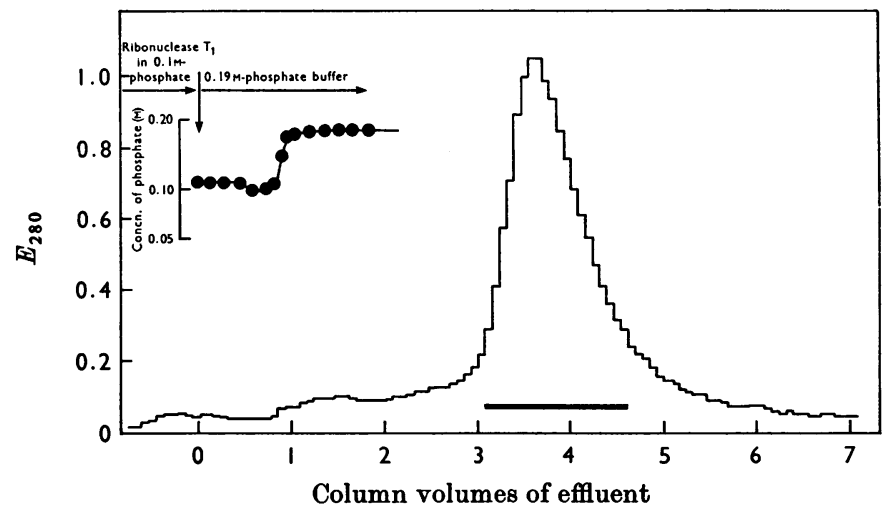

Fig. 3. Final equilibrium chromatography of ribonuclease $T_{1}$. A column $(4 \mathrm{~cm}$ diam. $\times 60 \mathrm{~cm}$ high) of DEAEcellulose equilibrated to $0.1 \mathrm{~m}$-phosphate, $\mathrm{pH} 6.9$, was eluted with $0.19 \mathrm{M}$-phosphate buffer, $\mathrm{pH} 6.9$, after the sample of ribonuclease $\mathrm{T}_{1}$ in $0.1 \mathrm{M}$-phosphate had been applied. - $-E_{280} ; \bullet$, concn. of phosphate, determined by conductivity.

\section{Table 2. Summary of purification of ribonuclease $T_{1}$ from $500 \mathrm{~g}$ of Takadiastase $Y$}

For calculation of the yields as percentages of ribonuclease $T_{1}$ it should be noted that the original extract contains other ribonucleases that are separated by the first step. The yield in the pooled fractions of the ribonuclease $T_{1}$ peak (Fig. 1) was taken as $100 \%$.

\begin{tabular}{|c|c|c|c|c|c|}
\hline & $E_{280} \times$ total vol. $(\mathrm{ml})$ & $\begin{array}{l}\text { Ribonuclease } \\
\text { activity at } \\
\text { pH4.7 (mg of } \\
\text { ribonuclease } \mathrm{T}_{1} \\
\text { equivalent) }\end{array}$ & $\begin{array}{l}\text { Specific activity } \\
\text { (as defined in } \\
\text { the Methods } \\
\text { section) }\end{array}$ & $\begin{array}{c}\text { Yield ( } \% \text { of } \\
\text { total } \\
\text { ribonuclease } \\
\text { activity at } \\
\text { pH4.7) }\end{array}$ & $\begin{array}{c}\text { Yield ( } \% \text { of } \\
\text { ribonuclease } \\
\left.\mathrm{T}_{1}\right)\end{array}$ \\
\hline Original extract (20 litres) & 300000 & 760 & 4 & 100 & - \\
\hline After gradient chromatography & 7000 & 510 & 123 & 67 & 100 \\
\hline After removal of colour & 6250 & 505 & 144 & 66 & 99 \\
\hline After first chromatography & 1890 & 455 & 465 & 60 & 87 \\
\hline After second chromatography & 660 & 365 & 1050 & 48 & 71 \\
\hline
\end{tabular}

sample had been applied, the column was eluted with 0.19 m-phosphate. Fig. 3 shows the result. It should again be noted that the front of equilibration with the $0.19 \mathrm{M}$-phosphate buffer moves faster than the peak, which therefore travels down the column in a region already equilibrated. The active fractions were pooled, gelfiltered into water and freeze-dried.

Electrophoresis. Samples of ribonuclease $\mathrm{T}_{1}$ were analysed by polyacrylamide-gel electrophoresis according to the procedure of Davis (1964). Samples were also examined by the sodium dodecyl sulphate-polyacrylamide-gel technique of Shapiro \& Maizel (1969). Samples of ribonuclease $T_{1}$ in $8 \mathrm{M}$-urea were subjected to electrophoresis at $\mathrm{pH} 8.9$ in $3.5 \%$ gels containing $8 \mathrm{M}$-urea. After $2 \mathrm{~h}$ at $3 \mathrm{~mA} /$ tube, the gels were removed and stained with $1 \%$ Amido Black in $7 \%(\nabla / v)$ acetic acid. Samples (0.05 and $0.1 \mathrm{mg}$ ) of ribonuclease $\mathrm{T}_{1}$ were applied to $7.5 \%$ gels containing $0.1 \%$ of sodium dodecyl sulphate in a solution containing 0.5 part of $10 \%(w / v)$ sodium dodecyl sulphate, 0.05 part of 2-mercaptoethanol, 0.05 part of
M-phosphate, $\mathrm{pH} \mathrm{7,} 0.5$ part of glycerol and 3.9 parts of water, after incubation for $1 \mathrm{~min}$ at $100^{\circ} \mathrm{C}$. The gels were subjected to electrophoresis for $4 \mathrm{~h}$ at $10 \mathrm{~mA} /$ tube and were stained with $0.1 \%$ Coomassie Blue in $7 \%(v / v)$ acetic acid. For determination of molecular weight samples were applied and run with a marker mixture that contained lysozyme, glyceraldehyde 3-phosphate dehydrogenase and bovine serum albumin.

Detection of other enzymes. (a) Ribonuclease $\mathrm{T}_{2}$ (EC 2.7.7.17) activity appeared to pass largely unretarded through the column of DEAE-cellulose during the initial adsorption step. It could be recovered by titrating the effluent to $\mathrm{pH}$ 7.5 with $\mathrm{NaOH}$, diluting a further twofold with water and adsorbing the enzyme on a column of DEAE-cellulose that had been previously equilibrated with $10 \mathrm{~mm}$-phosphate buffer, pH 7.5. The non-lineargradient procedure of Uchida \& Egami (1967) was then followed and the enzyme was purified as described by them.

(b) Taka-amylase (EC 3.2.1.1) activity was almost 

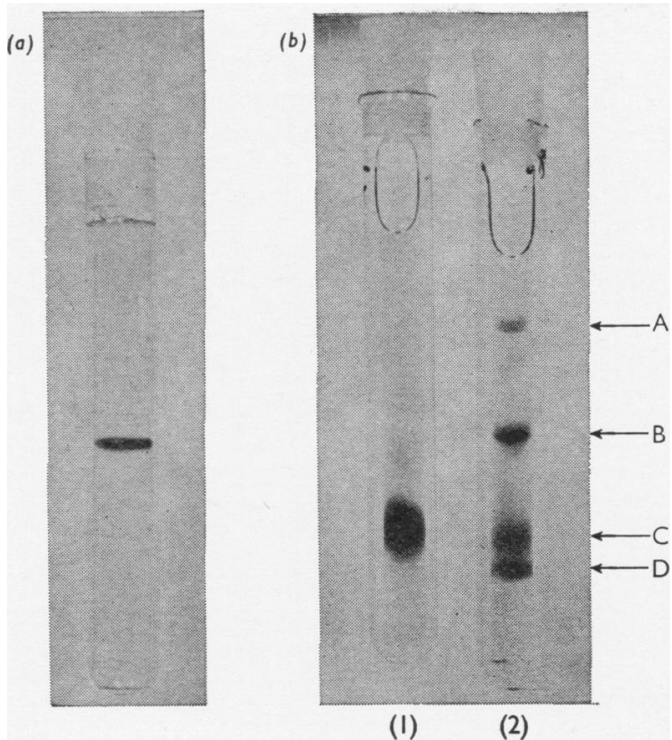

Fig. 4. Electrophoresis of ribonuclease $T_{1}$ in polyacrylamide gels. (a) $3.5 \%$ gel containing $8 \mathrm{M}$-urea, pH 8.9; the sample was $50 \mu \mathrm{g}$ from Takadiastase $Y$. (b) $7.5 \%$ gels containing $0.1 \%$ of sodium dodecyl sulphate, $\mathrm{pH} 7$; the sample was (1) $100 \mu \mathrm{g}$ prepared from Takadiastase $\mathrm{Y}$ or (2) $50 \mu \mathrm{g}$ (from Takadiastase $\mathrm{Y}$ ) (C) plus a reference mixture containing approx. $25 \mu \mathrm{g}$ each of $\mathrm{A}$, bovine serum albumin (mol.wt. 68 000), B, glyceraldehyde 3-phosphate dehydrogenase (mol.wt. 35000 ) and $D$, lysozyme (mol.wt. 14000). The samples were pretreated as described in the text.

totally adsorbed on the column during the initial loading step. The last quarter of the effluent showed increasing amounts of activity, presumably because the column was becoming saturated. The amylase could be precipitated from the pooled peak tubes by adding acetone to $55 \%$ $(\mathrm{v} / \mathrm{v})$ (Akabori, Ikenaka \& Hagihara, 1954) or the entire pool could be subjected to the rivanol-ammonium sulphate treatment described by these authors, followed by their subsequent purification procedure.

(c) Adenosine deaminase (non-specific) (EC 3.5.4.4) passed wholly unretarded through the column during the initial loading step.

\section{RESULTS}

The procedure described in detail yielded $365 \mathrm{mg}$ of ribonuclease $T_{1}$ from $0.5 \mathrm{~kg}$ of Takadiastase $Y$ (Table 2). This had a specific activity of 1050 measured by thestandard assaymethod of Takahashi (1961). When the same procedure was applied to the much cheaper Sanzyme 3500, a yield of $373 \mathrm{mg}$ of ribonuclease $T_{1}$ having nearly identical specific activity was obtained.
Electrophoresis of samples of ribonuclease $T_{1}$ prepared from Takadiastase $\mathbf{Y}$ in urea-polyacrylamide gels at pH 8.9 showed the presence of only one major band, with traces of material that moved more slowly towards the anode (Fig. 4a). As the contaminating substances appear to constitute a very small fraction of the sample, no attempt to characterize them was made. There was slightly more of them in a sample prepared from Sanzyme 3500 .

The samples gave one band on sodium dodecyl sulphate-polyacrylamide gels (Fig. 4b). The mobility of the band suggested a molecular weight of about 18000. The total amino acid analysis of the enzyme was not significantly different from that obtained by Takahashi (1962), and his enzyme was well characterized as having a molecular weight of 11000. Anomalous electrophoretic mobilities on sodium dodecyl sulphate gels of proteins of small molecular weight have been reported (Dunker \& Rueckert, 1969).

We thank Professor F. Egami for discussion and for gifts of Takadiastase powder. We thank Sankyo Company Ltd. for their gifts of purified ribonuclease $T_{1}$ and Takadiastase powders. We are grateful to Mr Ian Gibbons for helpful discussion and for performing the amino acid analysis and to Dr Tony Hunter for performing the electrophoreses in sodium dodecyl sulphate gels. We thank the Science Research Council and the Smith, Kline and French Foundation for financial support. R. F. thanks King's College, Cambridge, for a grant.

\section{REFERENCES}

Akabori, S., Ikenaka, T. \& Hagihara, B. (1954). J. Biochem., Tokyo, 41, 577.

Barnard, E. A. (1969). A. Rev. Biochem. 38, 677.

Brownlee, G. G., Sanger, F. \& Barrell, B. G. (1968). J. molec. Biol. 34, 379.

Davis, B. J. (1964). Ann. N.Y. Acad. Sci. 121, 404.

Dixon, H. B. F. \& Thompson, C. M. (1968). Biochem.J. $107,427$.

Dunker, A. K. \& Rueckert, R. R. (1969). J. biol. Chem. 244, 5074.

Egami, F. \& Nakamura, K. (1969). In Microbial Ribonucleases, p. 19. Ed. by Kleinzeller, A., Springer, G. F. \& Wittman, H. G. Berlin: Springer-Verlag.

Fuwa, H. (1954). J. Biochem., Tokyo, 41, 583.

Holley, R. W., Apgar, J., Everett, G. A., Madison, J. T., Marquisee, M., Merrill, S. H., Penswick, J. R. \& Zamir, A. (1965). Science, N.Y., 147, 1462.

Kalnitsky, G., Hummel, J. P. \& Dierks, C. (1959). J. biol. Chem. 234, 1512.

Kartha, G., Bello, J. \& Harker, D. (1967). Nature, Lond., 213, 862.

Minato, S., Tagawa, T. \& Nakanishi, K. (1965). J. Biochem., Tokyo, 58, 519.

Mohr, S. C. \& Thach, R. E. (1969). J. bial. Chem. 244, 6566. 
Shapiro, A. L. \& Maizel, J. V. (1969). Analyt. Biochem. $29,505$.

Takahashi, K. (1961). J. Biochem., Tokyo, 49, 1.

Takahashi, K. (1962). J. Biochem., Tokyo, 51, 95.

Takahashi, K., Uchida, T. \& Egami, F. (1970). $A d v$. Biophys., Tokyo, 1, 53.

Uchida, T. (1965). J. Biochem., Tokyo, 57, 547.
Uchida, T. \& Egami, F. (1967). In Methods in Enzymology, vol. 12A, p. 239. Ed. by Colowick, S. P. \& Kaplan, N. O. New York: Academic Press Inc.

Wyckoff, H. W., Hardman, K. D., Allewell, N. M., Inagami, T., Johnson, L. N. \& Richards, F. M. (1967). J. biol. Chem. 242, 3984. 